\title{
The Implementation of Constructivism Learning Models to Improve The Comprehending of Physics Concepts on Vibration And Wave Materials on Students of Seventh Grade At Second Semester in MTSN 2 Wolowaru
}

\author{
Kuran Mbadhi ${ }^{*}$, Melkyanus B.U. Kaleka ${ }^{2}$, An Nisaa Al Mumin Liu ${ }^{3}$ \\ ${ }^{1,2,3}$ Study Program of Physics Education, Faculty of Teacher Training and Education, Universitas Flores \\ Corresponding Author. Email: kuran@gmail.com
}

Keywords:

Constructivism

Learning, Concept

Comprehending,

and Vibrations and

waves

\begin{abstract}
The problem statement of the research was: does the implementation of the constructivism learning model improve the comprehending of physics concepts in the vibration and wave material of students in seventh-grade of MTS Negeri Wolowaru? The research aimed to determine the implementation of the constructivism learning model in improving the comprehending of the physics concept in the vibration and wave material of students in seventh-grade of MTS Negeri Wolowaru. The research used a quantitative approach. The population of the study was 60 students of seventh-grade of MTS Negeri Wolowaru. Meanwhile, the sample was 20 students selected through a random sampling technique. The data were the test results of the vibration and wave material. Data analysis was performed by the t-test. Based on data analysis and discussion, it concluded that the implementation of the constructivism learning model improved the students' comprehending of physics concepts on vibration and wave material. This conclusion was proved by the results of data analysis, namely $t_{\text {calculate }}>t_{\text {table }}=4.395>1.729$ at the significant level $=0.05$ and $d k=19$.
\end{abstract}

C2020 JSER. Yogyakarta State University

\section{INTRODUCTION}

Physics plays an important role in the era of globalization. With the existence of physics, all science becomes more perfect. Therefore, physics lessons are taught starting from secondary education to college. Also, physics receives top priority to be developed as physics is a tool to solve the problems in everyday life.

These approaches make the level of students' activeness in participating and comprehending the concepts tend to decrease low and, sometimes, they become bored. A constructivism method is an approach that allows high student activity and selfbuilding the students' knowledge in learning by finding real problems in everyday life, and constructed and developed by students as a starting point for learning physics aiming to show that physics is close to everyday life, through active involvement in the teaching and learning process (Trianto, 2007).

The most important thing in a learning process is the achievement of learning objectives, namely students have good comprehension based on their learning experience. This ability to understand is very fundamental due to, by understanding; it could achieve comprehension of the procedure.

Purwanto (1994) argues comprehension is the level of ability that requires students to understand the meaning or concept, situation, and facts they know. Meanwhile, Mulyasa (2002) states, comprehension is the cognitive and affective possessed by individuals, that they can capture meanings, for example, can express material presented in another form, as well as provide interpretations and classify it.

Sudjana (2010) states, comprehension are the level of ability that expects students to understand the meaning of concepts, situations, and facts. Comprehending is a conception understood by students so that they comprehend what is meant, find ways to argue these conceptions, and explore related possibilities.

Based on the definition of comprehending argued by the experts, concluded that comprehending is a systematic way of understanding and expressing knowledge. In Bloom's cognitive domain taxonomy, 
comprehending is divided into three aspects. They are:

a. The translation is the ability to change certain symbols into other symbols without changing the meaning of symbols, such as the words (verbal) converted into pictures, charts, or graphs.

b. Interpretation is the ability to explain the meaning of symbols, both verbal and non-verbal symbols, including the ability to explain concepts, principles, or theories. A person can interpret a concept or principle when can explain in detail the meaning of a concept or principle, or can compare and contrast with something else.

c. Extrapolation (ability to predict) is the ability to see trends, direction, or continuity of a finding. This type of comprehension ability demands higher intellectual abilities, for example, predict the possibilities.

Whereas a concept is an abstract idea that allows us to classify objects, or events are examples but not examples of the idea.

Based on observations at MTS Negeri Wolowaru, especially physics teachers, found that the learning uses lecturing method and have never implemented the constructivism learning model. In this case, the learning classifies as passive learning, in which students only listen and record the material without having an initial understanding of the material. Its impact on students that they do hesitate to ask questions, which certainly, results in students less interest in repeating lessons learned at school. Also, the material is rarely linked in real life, so that students often think that the material is useless for everyday life. As an impact, students do not play an active role in gaining understanding and comprehending the concept of physics.

A learning method following the needs of students is a step taken by the teacher as an effort to influence the student comprehending to achieve it classically. The use of the constructivist approach is a method to overcome difficulties in physics learning (Mulyasa, 2002).

Constructivism learning improves creative and critical thinking skills, and train students to think critically to solve problems, find ideas and decisions making, which seen in the following activities (Sukardi, 2005): (a) Student-centered learning, (b) Learning activities based on hands-on and minds-on, (c) Students express opinion about a concept, (d) Students learn and work in groups, and (e) Students apply their knowledge in solving problems.

According to Mulyasa (2002), constructivism learning shows that learning is an active process in obtaining experience into reality, and this process is strongly influenced by what people previously know. Therefore, the teacher must reach or have a common understanding with students in every learning activity. In constructivism, learning involves an exchange of thoughts and interpretations. This mind adjustment discourse is done between student and teacher or between student and student.

Budinigsih (2004) states, in the view of constructivism, learning is a process of formation that must always perform by students, do active thinking activities, compile concepts and give meaning to the things in the process of learning. The constructivism paradigm views students as individuals who already have initial abilities that are simple or different from the teacher, and, it should be accepted and used as a basis for learning and guidance.

Moreover, it should consider the advantages and disadvantages. Song (2006) mentions the advantages of constructivism learning: (1) the teacher play as a helper, facilitator, and designer, (2) applying the value of cooperation and collaboration, (3) not using traditional rules or techniques such as directions, memorization, and remembering, and (4) mastery the oral techniques and oral books. In contrast to advantages, the weaknesses of constructivism learning are: (1) students cannot assimilate and compile new scientific ideas, (2) students are unwilling to design thinking strategies and self-assess teaching theories based on their own experiences, and (3) students are forced to recognize alternative ideas and examine critically before they understand it. The steps for implementing constructivism learning according to (Aqrb, 2020) are: (1) the teacher encourages discussion of new knowledge that students have previously had; (2) motivating to think by linking the previous material with the material to be delivered, and solving problems using more than one correct answer, (3) involving students into learning activities, such as playing roles, simulating, debating, and giving explanations to friends; and (4) Using critical thinking skills by analyzing, comparing, generalizing, predicting and proposing hypotheses on the discussed problem.

Based on the previous description in the theoretical study, the research aimed to know the implementation of the constructivism learning model in improving the comprehending of the physics concepts in the vibration and wave material of the students in seventh-grade of MTS Negeri Wolowaru with minimal obtaining the score of 70 on KKM (Minimal Completion Criteria).

\section{METHOD}

The type of research was experimental research with a quantitative approach. An approach that uses calculations and numbers based on 
statistical analysis aimed to assist the researchers in solving the problems. The research was conducted at MTS Negeri Wolowaru. And, it conducted on the even semester of the 2015/2016 academic year for four months, starting from February to May 2016. The design used a pre-experimental design (oneshot case study) with the following chart: (Arikunto, 2012).

Table 3.1 Research Design

\begin{tabular}{cccc}
\hline Class & Treatment & Post-test & Result \\
\hline KE & $\mathrm{X}$ & $\mathrm{X} 2$ & $\mathrm{Y}$
\end{tabular}

Where:

KE: Experiment class

X2: Post-test

$\mathrm{X}$ : Science learning with constructivism method Y: Result

The data collection technique was a test technique, namely essay questions. The test was given at the end of the learning. And, it was an essay test for the learning outcome. The instrument validity was through by comparing the contents of the instrument with the material of the learning. The tests had ten items of the essay. Data technique is a method used to process data obtained at the research site. The collected data is processed and analyzed using statistical equations.

\section{Normality Test}

A normality test was used to find out the normality of the data. The equation for the normality test (Riduwan, 2012: 219) was:

$$
x^{2}=\sum\left[\frac{\left[f_{0}-f_{x}\right)^{2}}{f_{x}}\right]
$$

$$
\begin{aligned}
& \text { Where: } \\
& \begin{array}{l}
x^{2}=\text { The value of chi squared } \\
f_{0}=\text { Expected Frequency } \\
f_{e}=\text { Frequency of observation }
\end{array}
\end{aligned}
$$

The data was normal if: $x^{2}$ calculate $<x^{2}$ table, at the significant level $\alpha=0.05$ and degrees of freedom $(\mathrm{dk})=\mathrm{n}-2$.

\section{T-Test}

Then, the obtained data was processed and analyzed using statistical equations, and continued to t-test, calculated by the following equation (Riduwan, 2012: 160):

$$
t=\frac{\bar{R}-p_{0}}{\frac{5}{\sqrt[3]{n}}} \text {. }
$$

Where:

$\mathrm{t}=$ Calculated score

$X \quad=$ Mean

$\mu_{0}=$ Hypothesized score
$\mathrm{S}=$ Standard deviation of the calculated sample

$n=$ number of research samples

\section{RESULT}

The findings of the study are presented in the form of graphs, tables, or descriptions. Analysis and interpretations of these results is required before being discussed.

The table is put in the middle or at the end of each description of research findings. If the table is not enough to be written in a half-page, it can be fully be written in one page. Caption should be put on the top and centered. Each word is capitalized, except the conjunctions. If the caption is more than one line, it is written in a single space. The example can be seen in Table 1 .

The collected data was the comprehending of the physics concept. Based on observations during the learning process, 20 students on the class of experiment testing with 10 items of essays, obtained the score of comprehending of the physics concept that was presented in table 4.1:

\begin{tabular}{lc}
$\begin{array}{c}\text { Table 4.1. Table of Description data on } \\
\text { comprehending of the physics concept }\end{array}$ \\
\hline & $\begin{array}{c}\text { comprehending of the } \\
\text { physics concept }\end{array}$ \\
\hline Total of Students & 20 \\
Highest Score & 94 \\
Lowest Score & 65 \\
Mean & 78 \\
Median & 78,5 \\
Varian & 67,05 \\
Standard & 8,18 \\
Deviation &
\end{tabular}

\section{Test of Prerequisite Analysis}

Normality test

With a significance level of $5 \%$ and $\mathrm{dk}=\mathrm{k}-3$ $=5-3=2$, it obtained $x_{\text {table }}^{2}=5.991$. From the calculation obtained:

The comprehending of the physics concept, using the table $x^{2}$, obtained $x_{\text {table }}^{2}=5.991$ and $x_{\text {caleulate }}^{2}=4,218$. Because $\chi_{\text {caleulate }}^{2}<x^{2}$ table or $4.218<5.991$, it concluded that the data of test score for comprehending of the physics concept from the sample class was normally distributed.

\section{Hypothesis Test}

Based on the data analysis of the hypothesis test using a t-test, it obtained that $t_{\text {calculate }}=4.395$ and $\mathrm{t}_{\text {table }}=1.729$ at the significant level $(\alpha=0.05)$ with $\mathrm{dk}=\mathrm{n}-1$. And, it concluded that the implementation of the constructivism learning model improves the comprehending of the physics concepts on vibration and wave material for 
seventh-grade students of MTSN Wolowaru in the second semester.

Constructivism learning is an approach that allows high student activity and the importance of self-building knowledge through finding factproblems in everyday life. Through constructivism learning, students will be invited to learn and find fact-problems in daily life so that students, hopefully, be more motivated in learning. Also, the teacher gives perceptions at the beginning of the learning activity aiming the students have high motivation to learn and understand the benefits of learning since the beginning of the learning activity. In constructivism learning, the researcher, firstly, provides an overview related to vibration and wave material, and students are asked to mention examples associated with daily life, such as sea waves, earthquakes, and so on. Seen from the student's response when the researcher fosters student interest by presenting videos of earthquakes and asking questions about the process of earthquakes, students were actively looking for answers, and some students raised their hands and answers these questions. This process aims to ensure students' comprehending of the material concepts that lead to an active learning process between students and teachers. As a result, there is an increasing comprehension of physics concepts.

In the constructivism learning process, the researcher went through several steps; before the researcher asked the questions, the researcher provides a question guideline that aims to provide an overview for students. Then, students answer essays questions with fellow students carefully. The result, learning can stimulate students to active think critically, logically, and creatively. Besides, the teacher guides every student who is experiencing learning difficulties and motivation aiming the students always be active and focus on learning. This learning will make the students feel enthusiastic involving in learning.

The students' enthusiasm was seen from students when answering questions in front of the class. And, the teacher always gives awards to students, such as praise, applause, and attention regarding the student answers. Here, the students feel appreciated. Moreover, students who previously felt afraid, ashamed, and not confident were always motivated by the teacher to brave in class. Besides that, there an increase in the number of students who actively asked and answered questions and made notes. This is always related to the efforts of teachers who always motivate students to be actively involved in teaching and learning activities. Other factors that influence the comprehending of the physics concepts are interest and motivation. Before closing the learning activities, students and teachers together conclude the material. It aimed to conduct an assessment of understanding the concept of physics.

From several stages of the learning process, there is an increase in comprehending the physics concept that proved from the samples treated with the constructivism learning model have shown the score on comprehending the physics concepts.

Proved by the research conducted at a significant level $(\alpha)=0.05$ and obtained $t_{\text {calculate }}$ (4.395) $>t_{\text {table }}(1.729)$. In short, it concluded that the implementation of the constructivism learning model improves the comprehending of the physics concept in the vibration and wave material of seventh-grade of MTS Negeri Wolowaru in the second semester.

\section{CONCLUSION}

\section{Conclusion}

Based on the discussion, it concluded that the implementation of the constructivism learning model improves the comprehending of the physics concept in the vibration and wave material of seventh-grade MTS Negeri Wolowaru in the second semester. Proved by the ratio of $t_{\text {calculate }}>t_{\text {table }}=$ $4.395>1.729$ and $\mathrm{dk}=20-1=19$ at $\alpha=0.05$.

\section{Suggestions}

\section{Students}

The article proposes suggestions, as follows:

Constructivism learning has better cognitive skills and abilities and creating active interactions between students and teachers which makes the teaching and learning activities active and wellorganized. Then, the students are more active in participating in learning activities which leads to obtaining a more optimal concept comprehending.

\section{Teachers}

Teachers are suggested in presenting the material of physics, consider the teaching methods and students' skills aiming the teaching and learning activities are well-organized following the goals and the material are well-received by students effectively. Also, the teacher should provide motivation and develop student's creativity in the learning process. Thus, student activity can be further improved to reach optimal comprehending of concepts.

3. School

For formal education institutions, they should consider students' cognitive skills and abilities on the material. Here, the school party should prepare facilities and infrastructure to support student activities in the learning process.

\section{REFERENCES}

Aqrb. (2020). Inovasi Pembelajaran. Jakarta: Erlangga. 
Kuran Mbadhi, Melkyanus B.U. Kaleka, An Nisaa Al Mumin Liu / JSER 2020, 4(2), 59

Arikunto, S. (2012). Prosedur Penelitian Suatu Pendekatan Praktek. Jakarta: Rineka Cipta.

Budinigsih. (2004). Inovasi Pembelajaran. Yogyakarta: Ombak.

Mulyasa. (2002). Metodologi dan Pendekatan Pembelajaran. Jakarta: Erlangga.

Purwanto. (1994). Sains Fisika untuk SMP kelas VIII (II). Jakarta: Erlangga.

Song, S. (2006). Strategi Pembelajaran. Jakarta: Kencana.
Sudjana, N. (2010). Dasar-Dasar Proses Belajar Mengajar. Bandung: Sinar Baru Algensindo.

Sukardi. (2005). Strategi Pembelajaran. Jakarta: Kencana.

Trianto. (2007). Strategi Pembelajaran. Jakarta: Kencana. 